\title{
PENERAPAN PENDEKATAN KONTEKSTUAL (CONTEXTUAL TEACHING AND LEARNING) DALAM UPAYA MENINGKATKAN KETERAMPILAN MENULIS LAPORAN
}

\author{
Oleh: Anwar Sanusi, S.Pd.
}

\begin{abstract}
This research aims to improve writing skills report grade $V$ SD Negeri Kahuripan Bantarkalong by using a contextual approach (CTL). This research was carried out for three months, starting August until October 2012. This research study shaped the action class. Qualitative research used descriptive strategies. The subject of this study are students and teachers of the class V SD Negeri Kahuripan Bantarkalong totalling 36 students comprising 21 men and 15 women. Source of research data in the form of events the learning process of writing the report, teachers and students, as well as related documents. Data collection techniques in the study was observational, interviews, tests, and analysis of documents. Technique of data analysis used the technique of descriptive comparative critical-analytical description of data and findings by comparing it with the performance indicators that are already determined. The results showed that the mean results of observations against the activities of students during the following cycle learning cycle I, II, and III cycle there is always increasing. Average writing ability test results description of grade V SD Negeri Kahuripan Bantarkalong on initial conditions the value of the average 70.41 rate ketuntasan of classical 33.33\%. On cycle I, the mean value of classical 52.77 ketuntasan level 74.11\%. Cycle II, the mean value of classical ketuntasan level 75 77\%. Cycle III, the average value of classical 97.22 ketuntasan level 79\%. So for the rest of the cycle has been implemented, it can be concluded that the application of the contextual approach (CTL) turns can improve writing skills report grade V SD Negeri Kahuripan Bantarkalong. In each cycle always bring a positive impact towards the enhancement of student learning outcomes. In addition with the application of the contextual approach (CTL) brings the atmosphere of a class be conducive, students become interested, active and no saturation.
\end{abstract}

Keywords: Report writing skills, Contextual Approach (CTL)

\begin{abstract}
ABSTRAK
Penelitian ini bertujuan untuk meningkatkan keterampilan menulis laporan siswa kelas V SD Negeri Kahuripan Bantarkalong dengan menggunakan pendekatan kontekstual (CTL). Penelitian ini dilaksanakan selama tiga bulan, mulai Agustus sampai dengan Oktober 2012. Penelitian ini berbentuk penelitian tindakan kelas. Strategi penelitian digunakan deskriptif kualitatif. Subjek penelitian ini adalah siswa dan guru kelas V SD Negeri Kahuripan Bantarkalong yang berjumlah 36 siswa yang terdiri dari 21 laki-laki dan 15 perempuan. Sumber data penelitian berupa peristiwa proses pembelajaran menulis laporan, guru dan siswa, serta dokumen terkait. Teknik pengumpulan data dalam penelitian ini adalah pengamatan, wawancara, tes , dan analisis dokumen. Teknik analisis data digunakan teknik deskriptif analitis kritis-komparatif dengan mendeskripsikan temuan data dan membandingkannya dengan indikator kinerja yang sudah ditentukan.
\end{abstract}


Hasil penelitian menunjukkan bahwa rerata hasil observasi terhadap aktivitas siswa selama mengikuti pembelajaran pada siklus I, pada siklus II, dan pada siklus III selalu ada peningkatan.Hasil rerata tes kemampuan menulis deskripsi siswa kelas V SD Negeri Kahuripan Bantarkalong pada kondisi awal nilai rerata 70,41 tingkat ketuntasan klasikal $33,33 \%$. Pada siklus I, nilai rerata 74,11 tingkat ketuntasan klasikal 52,77 \%. Pada siklus II, nilai rerata 77 tingkat ketuntasan klasikal $75 \%$. Pada siklus III, nilai rerata 79 tingkat ketuntasan klasikal 97,22 \%. Jadi dari keseluruhan siklus yang telah dilaksanakan, dapat disimpulkan bahwa penerapan pendekatan kontekstual (CTL) ternyata dapat meningkatkan keterampilan menulis laporan siswa kelas V SD Negeri Kahuripan Bantarkalong. Dalam setiap siklus selalu membawa dampak positif ke arah peningkatan hasil belajar siswa. Selain itu dengan penerapan pendekatan kontekstual (CTL) membawa suasana kelas menjadi kondusif, siswa menjadi tertarik, aktif dan tidak ada kejenuhan.

Kata kunci : Keterampilan Menulis Laporan, Pendekatan Kontekstual (CTL)

\section{PENDAHULUAN}

Dalam pembelajaran Bahasa Indonesia di kelas V SD Negeri Kahuripan Bantarkalong, Menulis laporan pengamatan/kunjungan berdasar tahapan (catatan, konsep awal, perbaikan, final) dengan memperhatikan penggunaan ejaan sebagai salah satu kompetensi dasar yang harus dicapai ternyata menghadapi permasalahan sehingga dapat dikatakan belum berhasil pencapaiannya secara maksimal sesuai dengan kreteria ketuntasan minimal (KKM) yang ditetapkan (nilai 75). Dari 36 siswa yang mendapat nilai tuntas di atas KKM ada $12(33,33 \%)$ siswa dan yang mendapat nilai di bawah KKM ada $24(66,66 \%)$ siswa dengan nilai rata-rata kelas 70,41 Permasalahan yang muncul , ketika menulis laporan tersebut diajarkan di kelas adalah siswa kurang berminat, tidak tertarik, dan rendahnya antusias mereka dalam mengikuti pembelajaran sehingga semangat dan gairah belajarnyapun sangat kurang.

Pembelajaran menulis laporan yang terjadi di kelas tersebut sangat bersifat teoritis, monotun dan menjemukan. Guru lebih banyak menggunakan metode ceramah sebagai andalannya dalam menjelaskan materi menulis yang diajarkan. Pembelajaran lebih berpusat pada guru (teacher center). Keadaan pembelajaran yang demikian, tentu tidak akan dapat menopang terhadap percepatan pencapaian kompetensi dasar pembelajaran yang telah ditentukan, khususnya kompetensi menulis laporan. Untuk mengatasi hal tersebut, perlu diupayakan bentuk pembelajaran menulis laporan yang lebih memberdayakan siswa, yakni pembelajaran dengan menggunakan pendekatan Contextual Teaching and Learning (CTL). Pendekatan CTL merupakan konsep belajar yang membantu guru mengaitkan antara materi yang diajarkan dengan situasi dunia nyata siswa dan mendorong siswa membuat hubungan antara pengetahuan yang dimilikinya dengan penerapannya dalam kehidupan meraka sebagai anggota keluarga dan masyarakat. Dengan upaya tersebut, diharapkan kompetensi dasar yang harus dicapai dalam pembelajaran dapat tercapai sesuai dengan yang diharapkan.

Bertitik tolak pada pemikiran di atas, maka perlu diadakan penelitian tindakan kelas dengan judul "Penerapan Pendekatan Kontekstual (Contextual Teaching and Learning) dalam Upaya Meningkatkan Keterampilan Menulis Laporan Siswa Kelas V SD Negeri Kahuripan Semester I Tahun Pelajaran 2011/2012”. Terkait dengan uraian 
tersebut, maka dirumuskan permasalahan : (1) Apakah dengan menerapkan pendekatan kontekstual, proses pembelajaran menulis laporan di kelas V SD Negeri Kahuripan Bantarkalong dapat ditingkatkan? (2) Apakah dengan menerapkan pendekatan kontekstual, keterampilan siswa kelas V SD Negeri Kahuripan Bantarkalong dalam menulis laporan dapat ditingkatkan?

\section{KAJIAN TEORITIS}

\section{Hakekat Ketrampilan Menulis Laporan}

Kata keterampilan yang melekat pada frasa (kelompok kata) "keterampilan menulis laporan" pada penelitian ini memiliki acuan pengertian yang sepadan dengan salah satu kategori keluaran belajar yang disebutkan Gagne dan Briggs di atas, yaitu ketrampilan intelektual. Dijelaskan oleh Winkel (1991 : 73), yang dimaksud keterampilan intelektual adalah ketrampilan untuk berhubungan dengan lingkungan hidup dan dirinya sendiri dalam bentuk representasi, khususnya konsep dan berbagai lambang/simbol (huruf, angka, kata, gambar). Menurut Muhibbin Syah (2000 : 119) keterampilan bukan hanya meliputi gerakan motorik melainkan juga pengejawantahan fungsi mental yang bersifat kognitif. Jadi, keterampilan intelektual di sini berkenaan dengan kecekatan orang dalam mendayagunakan segala fungsi mental/kognitifnya untuk mencapai hasil secara maksimal.

Menulis adalah suatu kegiatan penyampaian pesan dengan menggunakan tulisan sebagai mediumnya. Pesan adalah isi atau muatan yang terkandung dalam suatu tulisan. Adapun tulisan merupakan sebuah sistem komunikasi antar manusia yang menggunakan symbol atau lambang bilangan yang dapat dilihat dan disepakati pemakainya (Sabarti Akhadiah, 1998: 1.3).

Laporan berarti segala sesuatu yang dilaporkan oleh pihak tertentu kepada pihak lain mengenai suatu masalah, baik secara lisan maupun tertulis, dan baik dalam kurun waktu tertentu secara rutin maupun dalam waktu tertentu saja (Anwar Hasnun, $2006: 30$ ) Mengacu pada pengertian yang dikemukakan oleh Anwar Hasnun ini, yang dimaksud dengan laporan pada penelitian tindakan kelas ini adalah laporan hasil pengamatan siswa setelah mereka berkunjung atau mengamati ruang perpustakaan di sekolah mereka.

Jadi yang dimaksudkan dengan keterampilan menulis laporan ini adalah keterampilan siswa dalam melaporkan segala sesuatu yang diamati ketika mereka berkunjung atau mengamati perpustakaan sekolah dengan bahasa Indonesia tulis yang runtut, jelas, baik dan benar.

\section{Hakikat Pendekatan Kontekstual ( Contextual Teaching and Learning)}

Pendekatan adalah seperangkat asumsi korelasi yang menangani hakikat pengajaran dan pembelajaran bahasa . Pendekatan memerikan hakikat pokok bahasan yang diajarkan (Depdiknas, 2004e : 70)

Metode merupakan rencana keseluruhan bagi penyajian bahan bahasa secara rapi dan tertib, yang tidak ada bagian-bagiannya yang dikontradiksi, dan kesemuanya itu didasarkan pada pendekatan yang dipilih. Pendekatan bersifat aksiomatis sedangkan metode bersifat prosedural. Di dalam satu pendekatan mungkin banyak terdapat metode. 
Pendekatan CTL, merupakan konsep belajar yang membantu guru mengaitkan antara materi yang diajarkan dengan situasi dunia nyata siswa dan mendorong siswa membuat hubungan antara pengetahuan yang dimilikinya dengan penerapannya dalam kehidupan mereka sebagai anggota keluarga dan masyarakat. Dengan konsep itu, hasil pembelajaran diharapkan bermakna bagi siswa. Proses pembelajaran berlangsung secara alamiah dalam bentuk kegiatan siswa bekerja dan mengalami, bukan transfer pengetahuan dari guru ke siswa. Strategi pembelajaran lebih dipentingkan daripada hasil (Depdiknas, 2002a : 1)

Dalam kelas CTL, tugas guru adalah membantu siswa mencapai tujuannya. Maksudnya, guru lebih banyak berurusan dengan strategi dari pada memberi imformasi. Tugas guru adalah mengelola kelas sebagai sebuah tim yang bekerja sama untuk menemukan sesuatu yang baru bagi anggota kelas (siswa) datang dari"menemukan sendiri” bukan dari “apa kata guru” (Depdiknas, 2002a : 2)

\section{Pembelajaran Pendekatan Kontekstual ( Contextual Teaching and Learning)}

Dalam kaitannya dengan pembelajaran dengan CTL, Blancard (2001) mengembangkan strategi pembelajaran CTL dengan : (1) menekankan pemecahan masalah, (2) menyadari kebutuhan pengajaran dan pembelajaran yang terjadi dalam berbagai konteks, seperti rumah, masyarakat, dan pekerjaan, (3) mengajar siswa memonitor dan mengarahkan pembelajaran mereka sendiri sehingga menjadi siswa mandiri, (4) Mengaitkan pengajaran pada konteks kehidupan siswa yang berbeda-beda, (5) mendorong siswa belajar dari sesama teman dan belajar bersama, dan (6) menerapkan penilaian autentik (dalam Depdiknas, 2004b : 45).

Pendekatan CTL memiliki tujuh komponen utama, yakni konstruktivisme (Constructivism), menemukan ( Inquiry), bertanya (Questioning), masyarakat belajar (Learning Community), pemodelan (Modeling), refleksi (Reflection), dan peneilaian sebenarnya ( Authentic Assessment). Pembelajaran di kelas dikatakan menggunakan pendekatan CTL jika menerapkan tujuh komponen utama (http://www.bpgupg.go.id/buletin/akademik/php)

\section{Pembelajaran Menulis dengan Pendekatan Kontekstual ( Contextual Teaching and Learning)}

Dengan diterapkannya pendekatan CTL , peranan siswa dalam pembelajaran menulis menjadi lebih diberdayakan. Ada beberapa hal yang perlu mendapat perhatian khusus agar proses pembelajaran dengan pendekatan CTL dapat berlangsung secara optimal, diantaranya : (1) perlu mengubah kebiasaan siswa yang terbiasa pasif sebagai penerima materi pelajaran dari guru menjadi aktif . (2) Perlu memotivasi siswa agar mau bertanya, memberikan tanggapan atau pendapat yang berkaitan dengan materi pelajaran. (3) Guru perlu "memenej" waktu sebaik-baiknya , misalnya pada saat mengatur kelompok, memajang hasil karya siswa (Sunardi,2005 : 34-35)

Secara garis besar, penerapan pendekatan CTL di dalam kelas dapat dilaksanakan dengan langkah : 
1) Mengembangkan pemikiran bahwa anak akan belajar lebih bermakna dengan cara bekerja sendiri, menentukan sendiri, dan mengkonstruksikan sendiri pengetahuan dan kompetensi barunya.

2) Melaksanakan sejauh mungkin kegiatan inquiry untuk semua topik.

3) Mengembangkan sifat ingin tahu siswa dengan bertanya.

4) Menciptakan masyarakat belajar (belajar dalam kelompok-kelompok).

5) Menghadirkan model sebagai contoh pembelajaran.

6) Melakukan refleksi di akhir pertemuan.

7) Melakukan penilaian yang sebenarnya dengan berbagai cara (Nurhadi, 2004 : 106)

Untuk menyusun strategi pembelajaran menulis laporan, ada sejumlah kegiatan yang perlu dipersiapkan. Adapun kegiatan itu mencakup : (1) Persiapan. (2) Penyusunan program pembelajaran. (3) Pelaksanaan program pembelajaran. (4) Pelaksanaan penilaian baik penilaian proses maupun penilaian hasil. (5) Pemanfaatan hasil penilaian. (6) Perencanaan tindak lanjut dari pemanfaatan hasil penilaian (Sunardi, $2005: 31$ )

Kegiatan-kegiatan yang terkait dengan kegiatan pembelajaran tersebut di atas adalah : (1) Mengidentifikasi model-model pengamatan belajar. (2) Mengidentifikasi langkah-langkah yang dilakukan baik pada tahap pendahuluan, tahap inti, maupun tahap akhir pembelajaran. (3) Mengidentifikasi teknik-teknik penyajian serta teknik pengelompokan siswanya. (4) Mengidentifikasi media atau sumber pembelajaran yang relevan dengan kompetensi yang telah ditentukan yang digunakan dalam pembelajaran (Depdiknas, 2004b : 15)

Secara garis besar, penerapan pembelajaran menulis laporan melalui pendekatan CTL, dilaksanakan dengan langkah : (1) Mengamati objek yang akan ditulis/dilaporkan;

(2) Mencatat unsur-unsur penting dari objek yang akan dilaporkan; (3) Menyusun kerangka laporan; (4) Menulis laporan sesuai dengan objek yang diamati; (5) Membentuk kelompok untuk berdiskusi; (6) Mendiskusikan hasil tulisan yang berbentuk laporan; (7) Memperbaiki laporan berdasarkan hasil diskusi dan arahan guru.

\section{Kerangka Berpikir}

Berdasarkan pada landasan teori yang diuraikan di atas dapat dijelaskan alur kerangka berpikir dalam penelitian sebagai berikut.

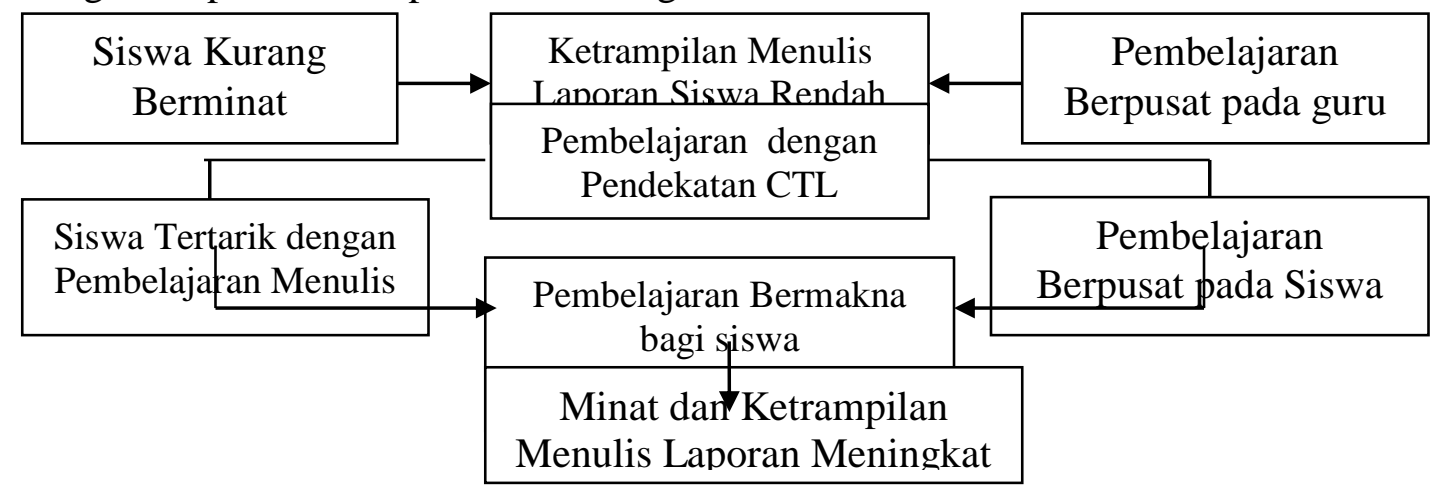

\section{Hipotesis Tindakan}

Alur Berpikir Pembelajaran CTL 
Hipotesis dalam penelitian tindakan kelas ini sebagai berikut: "Dengan penerapan pendekatan CTL dapat ditingkatkan : (1) proses pembelajaran menulis laporan; (2) hasil keterampilan menulis laporan siswa kelas V SD Negeri Kahuripan“

\section{METODE PENELITIAN}

Penelitian ini berbentuk Penelitian Tindakan Kelas (Classroom Action Research). Prosedur dalam PTK ini mencakup langkah-langkah: (1) persiapan, (2) studi/survei awal, (3) pelaksanaan siklus, dan (4) penyusunan laporan. Pelaksanaan siklus meliputi (a) perencanaan tindakan (planning), (b) pelaksanaan tindakan (acting), (c) pengamatan (observing), (d) refleksi (reflecting). Banyaknya siklus yang telah dilaksanakan ada tiga mengingat dalam penelitian tindakan ini, pada siklus terakhir (siklus III) telah mencapai indikator kinerja atau capaian yang telah ditetapkan.

Penelitian dilaksanakan selama 3 bulan yaitu bulan Agustus sampai Oktober 2010. Subjek penelitian tindakan kelas ini adalah siswa kelas V Kahuripan Bantarkalong Tasikmalaya, dengan jumlah siswa 36 yang terdiri dari 21 laki-laki dan 15 perempuan.

Sumber data pada penelitian tindakan kelas ini yaitu : (1) peristiwa proses pembelajaran menulis laporan; (2) informan; (3) dokumen.

Tehnik pengumpulan data yang dilakukan dalam penelitian ini sebagai berikut : (1) Observasi ; (2) Wawancara ; dan (3) Analisis dokumen

Data-data dalam penelitian ini diuji validitasnya dengan beberapa teknik triangulasi, yaitu triangulasi sumber data dan triangulasi metode. Trianggulasi sumber data, peneliti mengumpulkan data - data dari berbagai sumber yang berbeda. Trianggulasi metode, peneliti mengumpulkan data-data dari yang bersumber dari beberapa metode.

Teknik analisis data yang digunakan dalam penelitian ini adalah teknik analisis kritis. Analisis kritis terhadap keterampilan menulis laporan siswa mencakup isi yang dilaporkan, pengorganisasian isi tulisan, struktur kalimat, pilihan kata (diksi), dan tanda baca serta ejaan.

Indikator kinerja dalam PTK ini ditetapkan sebagai berikut: Paling sedikit $85 \%$ siswa memperoleh nilai 75 atau lebih sebagai batas tuntas mata pelajaran bahasa Indonesia, khususnya ketrampilan menulis laporan.

\section{HASIL PENELITIAN DAN PEMBAHASAN}

\section{Diskripsi kondisi awal}

Hasil tes kondisi awal sebelum dilaksanakan tindakan dapat dilihat tabel dibawah ini:

Tabel 1. Nilai Tes Keterampilan Menulis laporan pada Kondisi Awal

\begin{tabular}{|c|l|c|}
\hline No & \multicolumn{1}{|c|}{ Uraian Pencapaian Hasil } & Jumlah Nilai \\
\hline 1 & Jumlah Siswa dengan nilai $<75$ & 24 \\
\hline 2 & Jumlah Siswa dengan Nilai $\geq 75$ & 12 \\
\hline 3 & Nilai Rerata (Mean) Keterampilan Menulis Laporan & 70,41 \\
\hline 4 & Presentase Ketuntasan Klasikal & 33,33 \\
\hline
\end{tabular}

Nilai siswa yang disajikan pada tabel 1 di atas menunjukkan sebanyak 24 siswa memperoleh nilai di bawah 75. Sebanyak 12 siswa memperoleh nilai di atas atau sama 
dengan 75. Nilai rerata 70,41 dengan tingkat ketuntasan secara klasikal sebesar 33,33\%. Data ini menunjukkan bahwa pembelajaran menulis deskripsi, siswa belum memenuhi batas tuntas yang ditetapkan, yaitu $85 \%$ dari jumlah siswa yang ada harus memperoleh nilai 75.

\section{Deskripsi Siklus I}

Tingkat aktivitas siswa selama mengikuti pembelajaran menulis laporan berdasarkan hasil observasi pada siklus I, dapat disajikan sebagai berikut:

Tabel 2. Presentase Hasil Pengamatan Kegiatan Belajar Siklus I

\begin{tabular}{|c|l|l|c|}
\hline No & \multicolumn{1}{|c|}{ Unsur yang Diamati } & \multicolumn{1}{|c|}{ Kriteria } & Presentase \\
\hline 1 & Mengamati Objek Tulisan & Baik & $60 \%$ \\
\cline { 3 - 4 } & & Cukup & $30 \%$ \\
\cline { 3 - 4 } & & Kurang & $10 \%$ \\
\hline 2 & \multirow{2}{*}{$\begin{array}{l}\text { Kesungguhan dalam Menyusun Kerangka } \\
\text { Tulisan }\end{array}$} & Baik & $52,5 \%$ \\
\cline { 3 - 4 } & & Cukup & $47,5 \%$ \\
\cline { 3 - 4 } 3 & Kesungguhan dalam Menulis Laporan & Kurang & $0 \%$ \\
\cline { 3 - 4 } & & Baik & $62,5 \%$ \\
\hline 4 & \multirow{2}{*}{ Keaktifan dalam Berdiskusi } & Cukup & $37,5 \%$ \\
\cline { 3 - 4 } & & Kurang & $0 \%$ \\
\cline { 3 - 4 } & & Baik & $47,5 \%$ \\
\cline { 3 - 4 } & & Cukup & $40 \%$ \\
\cline { 3 - 4 } & & & \\
\end{tabular}

Hasil pembelajaran menulis laporan pada siklus I disajikan dalam tabel berikut :

Tabel 3. Nilai Keterampilan Menulis Laporan Siswa pada Siklus I

\begin{tabular}{|c|l|c|}
\hline No & \multicolumn{1}{|c|}{ Uraian Pencapaian Hasil } & Jumlah Nilai \\
\hline 1 & Jumlah Siswa dengan nilai $<75$ & 15 \\
\hline 2 & Jumlah Siswa dengan nilai $\geq 75$ & 19 \\
\hline 3 & Nilai Rerata (Mean) Keterampilan Menulis Laporan & 74,11 \\
\hline 4 & Presentase Ketuntasan Klasikal & $57,77 \%$ \\
\hline
\end{tabular}

Hasil tes keterampilan menulis laporan yang disajikan pada tabel 3 di atas, menunjukkan 15 siswa mendapat nilai kurang dari 75. Sebanyak 19 siswa mendapat nilai 75 atau lebih. Nilai rata-rata kelas 74,11 . Ketuntasan secara klasikal sebesar $52,77 \%$. Berdasarkan hasil tersebut, dapat diketahui bahwa proses pembelajaran menulis laporan siswa dapat dikatakan belum mencapai tujuan yang diharapkan.

\section{Deskripsi Siklus II}

Tingkat aktivitas siswa selama mengikuti pembelajaran menulis laporan berdasarkan hasil observasi pada siklus II, dapat disajikan sebagai berikut:

Tabel 4. Presentase Hasil Pengamatan Kegiatan Belajar Siklus II

\begin{tabular}{|l|c|c|c|}
\hline No & Unsur yang Diamati & Kriteria & Presentase \\
\hline
\end{tabular}




\begin{tabular}{|c|l|l|c|}
\hline 1 & Mengamati Objek Tulisan & Baik & $77,5 \%$ \\
\cline { 3 - 4 } & & Cukup & $22,5 \%$ \\
\cline { 3 - 4 } & & Kurang & $0 \%$ \\
\hline 2 & \multirow{2}{*}{\begin{tabular}{l} 
Kesungguhan dalam Menyusun Kerangka \\
\cline { 3 - 4 }
\end{tabular}} & Baik & $77,5 \%$ \\
\cline { 3 - 4 } & & Cukup & $22,5 \%$ \\
\cline { 3 - 4 } & \multirow{2}{*}{ Kesungguhan dalam Menulis Laporan } & Kurang & $0 \%$ \\
\hline & & Baik & $82,5 \%$ \\
\hline & & Cukup & $17,5 \%$ \\
\cline { 3 - 4 } & \multirow{2}{*}{ Keaktifan dalam Berdiskusi } & Kurang & $0 \%$ \\
\hline & & Baik & $57,5 \%$ \\
\cline { 3 - 4 } & & Cukup & $42,5 \%$ \\
\cline { 3 - 4 } & & Kurang & $0 \%$ \\
\hline
\end{tabular}

Hasil pembelajaran menulis laporan pada siklus I disajikan dalam tabel berikut :

Tabel 5. Nilai Keterampilan Menulis Laporan Siswa pada Siklus II

\begin{tabular}{|c|l|c|}
\hline No & \multicolumn{1}{|c|}{ Uraian Pencapaian Hasil } & Jumlah Nilai \\
\hline 1 & Jumlah Siswa dengan nilai $<75$ & 9 \\
\hline 2 & Jumlah Siswa dengan Nilai $\geq 75$ & 27 \\
\hline 3 & Nilai Rerata (Mean) Keterampilan Menulis Laporan & 77 \\
\hline 4 & Presentase Ketuntasan Klasikal & $75 \%$ \\
\hline
\end{tabular}

Hasil nilai pada tabel 5 di atas menunjukkan 9 siswa mendapat nilai kurang dari (di bawah) 75. Sebanyak 27 siswa mendapat nilai 75 atau lebih. Nilai rerata kelas 77. Ketuntasan secara klasikal sebesar 75\%. Berdasarkan hasil tersebut dapat diketahui bahwa nilai rerata yang dicapai sudah memenuhi batas KKM. Namun, secara klasikal belum mencapai batas tuntas sesuai dengan indikator kinerja yaitu $85 \%$.

\section{Deskripsi Siklus III}

Tingkat aktivitas siswa selama mengikuti pembelajaran menulis laporan berdasarkan hasil observasi pada siklus III, dapat disajikan sebagai berikut:

Tabel 6. Presentase Hasil Pengamatan Kegiatan Belajar Siklus III

\begin{tabular}{|c|l|l|c|}
\hline No & \multicolumn{1}{|c|}{ Unsur yang Diamati } & \multicolumn{1}{|c|}{ Kriteria } & Presentase \\
\hline 1 & Mengamati Objek Tulisan & Baik & $85 \%$ \\
\cline { 3 - 4 } & & Cukup & $15 \%$ \\
\cline { 3 - 4 } & & Kurang & $0 \%$ \\
\hline 2 & \multirow{2}{*}{$\begin{array}{l}\text { Kesungguhan dalam Menyusun Kerangka } \\
\text { Tulisan }\end{array}$} & Baik & $90 \%$ \\
\cline { 3 - 4 } & & Cukup & $10 \%$ \\
\cline { 3 - 4 } & & Kurang & $0 \%$ \\
\hline
\end{tabular}




\begin{tabular}{|c|l|l|c|}
\hline 3 & Kesungguhan dalam Menulis Laporan & Baik & $90 \%$ \\
\cline { 3 - 4 } & & Cukup & $10 \%$ \\
\cline { 3 - 4 } & & Kurang & $0 \%$ \\
\hline 4 & Keaktifan dalam Berdiskusi & Baik & $67,5 \%$ \\
\cline { 3 - 4 } & & Cukup & $32,5 \%$ \\
\cline { 3 - 4 } & & Kurang & $0 \%$ \\
\hline
\end{tabular}

Hasil pembelajaran menulis laporan pada siklus I disajikan dalam tabel berikut :

Tabel 7. Nilai Keterampilan Menulis Laporan Siswa pada Siklus III

\begin{tabular}{|c|l|c|}
\hline No & \multicolumn{1}{|c|}{ Uraian Pencapaian Hasil } & Jumlah Nilai \\
\hline 1 & Jumlah Siswa dengan nilai $<75$ & 1 \\
\hline 2 & Jumlah Siswa dengan Nilai $\geq 75$ & 35 \\
\hline 3 & Nilai Rerata (Mean) Keterampilan Menulis Laporan & 79 \\
\hline 4 & Presentase Ketuntasan Klasikal & $97,22 \%$ \\
\hline
\end{tabular}

Hasil nilai pada tabel 7 di atas menunjukkan 1 siswa mendapat nilai kurang dari (di bawah) 75. Sebanyak 35 siswa mendapat nilai 75 atau lebih. Nilai rerata kelas 79. Ketuntasan secara klasikal sebesar 97,22\%. Berdasarkan hasil tersebut dapat diketahui bahwa nilai rerata yang dicapai sudah memenuhi indikator kinerja yaitu $85 \%$ siswa telah mendapat nilai 75 atau lebih ke atas sebagai batas tuntas kompetensi dasar menulis laporan. Masih ada satu anak yang nilainya dari KKM.

\section{Pembahasan/Diskusi}

Dalam pembahasan ini ada 3 hal yang akan dibahas, yaitu meliputi tindakan, aktivitas belajar pembelajaran, dan hasil belajar siswa

1. Tindakan

\begin{tabular}{|l|l|l|l|}
\hline \multicolumn{1}{|c|}{ Kondisi Awal } & \multicolumn{1}{c|}{ Siklus I } & \multicolumn{1}{c|}{ Siklus II } & \multicolumn{1}{c|}{ Siklus III } \\
\hline $\begin{array}{l}\text { Belum menggunakan } \\
\text { tindakan CTL }\end{array}$ & $\begin{array}{l}\text { Menggunakan } \\
\text { pendekatan CTL } \\
\text { (pemodelan, }\end{array}$ & $\begin{array}{l}\text { Menggunakan } \\
\text { pendekatan CTL } \\
\text { (pemodelan, }\end{array}$ & $\begin{array}{l}\text { Menggunakan } \\
\text { pendekatan CTL } \\
\text { (pemodelan, }\end{array}$ \\
& $\begin{array}{l}\text { konstruktivisme, } \\
\text { refleksi) }\end{array}$ & $\begin{array}{l}\text { konstruktivisme, } \\
\text { bertanya, } \\
\text { masyarakat belajar, } \\
\text { refleksi) }\end{array}$ & $\begin{array}{l}\text { kenstruktivisme, } \\
\text { bertanya, } \\
\text { masyarakat belajar, } \\
\text { refleksi) }\end{array}$ \\
& & &
\end{tabular}

2. Aktivitas proses pembelajaran

\begin{tabular}{|l|l|c|c|c|}
\hline \multicolumn{1}{|c|}{ Unsur yang Diamati } & Kriteria & Siklus I & Siklus II & Siklus III \\
\hline \multirow{2}{*}{$\begin{array}{l}\text { Siswa. } \\
\text { 1. Mengamati Objek }\end{array}$} & Baik & 61,11 & 77,77 & 83,33 \\
\cline { 2 - 5 } $\begin{array}{l}\text { Tulisan } \\
\text { 2. }\end{array}$ & Kukup & 27,77 & 22,22 & 16,66 \\
\cline { 2 - 5 } $\begin{array}{l}\text { Kesungguhan dalam } \\
\text { menyusun kerangka }\end{array}$ & Baik & 11,11 & 0 & 0 \\
\cline { 2 - 5 } Tulisan & Cukup & 57,77 & 75 & 88,88 \\
\cline { 2 - 5 } & Kurang & 0 & 25 & 11,11 \\
\hline
\end{tabular}




\begin{tabular}{|l|l|c|c|c|}
\hline \multirow{3}{*}{$\begin{array}{c}\text { 3. Kesungguhan dalam } \\
\text { menulis Laporan }\end{array}$} & Baik & 63,88 & 83,33 & 88,88 \\
\cline { 2 - 5 } & Cukup & 36,11 & 16,66 & 11,11 \\
\cline { 2 - 5 } & Kurang & 0 & 0 & 0 \\
\hline \multirow{3}{*}{ 4. Berdiskusi } & Baik & 47,22 & 58,33 & 72,22 \\
\cline { 2 - 5 } & Cukup & 38,88 & 36,11 & 27,77 \\
\cline { 2 - 5 } & Kurang & 13,88 & 5,55 & 0 \\
\hline
\end{tabular}

3. Hasil belajar siswa

\begin{tabular}{|l|c|c|c|c|l|}
\hline \multicolumn{1}{|c|}{ Kriteria } & $\begin{array}{c}\text { Kondisi } \\
\text { Awal }\end{array}$ & $\begin{array}{c}\text { Siklus } \\
\text { I }\end{array}$ & $\begin{array}{c}\text { Siklus } \\
\text { II }\end{array}$ & $\begin{array}{c}\text { Siklus } \\
\text { III }\end{array}$ & \multicolumn{1}{c|}{ Refleksi } \\
\hline $\begin{array}{l}\text { Jumlah Siswa } \\
\text { dengan nilai } \\
75\end{array}$ & 24 & 15 & 9 & 1 & $\begin{array}{l}\text { Nilai kurang dari 75 dari kondisi } \\
\text { awal 24 ke siklus I menurun } \\
\text { menjadi 15, dari siklus I ke siklus II } \\
\text { menurun menjadi 9, dari siklus II } \\
\text { ke siklus III jumlahnya menurun } \\
\text { tinggal I anak yang nilainya kurang } \\
\text { dari 75 }\end{array}$ \\
\hline $\begin{array}{l}\text { Jumlah Siswa } \\
\text { dengan nilai }\end{array}$ & 12 & 19 & 27 & 35 & $\begin{array}{l}\text { Nilai 75 atau lebih dari kondisi } \\
\text { awal 12 ke siklus I naik menjadi } \\
19, \text { dari siklus I ke siklus II naik } \\
\text { menjadi 27, dari siklus II ke siklus } \\
\text { III naik menjadi 35 }\end{array}$ \\
\hline $\begin{array}{l}\text { Nilai Rerata } \\
\text { (Mean) }\end{array}$ & 70,41 & 74,11 & 77 & 79 & $\begin{array}{l}\text { Nilai rerata dari kondisi awal awal } \\
70,41 \text { ke siklus I naik menjadi } \\
74,11, \text { dari siklus I ke siklus II naik } \\
\text { menjadi 77, dari siklus II ke siklus } \\
\text { III naik menjadi 79, berarti } \\
\text { jumlahnya selalu meningkat }\end{array}$ \\
\hline $\begin{array}{l}\text { Ketuntasan } \\
\text { Klasikal }\end{array}$ & 33,33 & 52,77 & 75 & 97,33 & $\begin{array}{l}\text { Tingkat ketuntasan klasikal 85 \% } \\
\text { dari kondisi awal, ke siklus I, siklus } \\
\text { II } \\
\text { belum tercapai, pada siklus III } \\
\text { ketuntasan klasikal tercapai 97,33 } \\
\%\end{array}$ \\
\hline
\end{tabular}

\section{PENUTUP}

\section{Simpulan}

Berdasarkan hasil PTK yang dilakukan sebanyak tiga siklus dapat disimpulkan bahwa penerapan pendekatan kontekstual (CTL) sangat efektif untuk meningkatkan keterampilan menulis laporan siswa Kelas V SD Negeri Kahuripan Bantarkalong. Peningkatan hasil kemampuan menulis laporan dapat dilaporkan sebagai berikut: Pada kondisi awal, nilai rerata kemampuan menulis laporan siswa sebesar 70,41 dengan 
tingkat ketuntasan klasikal 33,33\%. Pada siklus I, nilai rerata siswa 74,11 dengan tingkat ketuntasan secara klasikal 52,77\%. Pada siklus II, nilai rerata siswa 77 dengan tingkat ketuntasan secara klasikal $75 \%$. Pada siklus III, nilai rerata siswa 79 dengan tingkat ketuntasan secara klasikal 97,22\%.

\section{Implikasi Hasil Penelitian}

Berdasarkan kajian teori serta Penerapan Pendekatan Kontekstual dalam Upaya Meningkatkan Keterampilan Menulis Laporan dalam penelitian tindakan kelas ini adalah sebagai berikut:

1. Mendapat teori baru tentang berbagai model pembelajaran (CTL) yang inovatif dan kreatif menuju pembelajaran yang aktif, inovatif, kreatif, efektif, dan menyenangkan

2. Sebagai dasar untuk melaksanakan penelitian tindakan kelas selanjutnya dalam rangka memperbaiki proses pembelajaran

\section{Saran}

1. Saran untuk siswa, agar dapat mengikuti dalam proses pembelajaran lebih aktif, dapat bekerja sama, dengan suasana yang menyenangkan tanpa rasa takut atau tekanan.

2. Saran untuk guru, (1) khususnya guru yang mengajarkan mata pelajaran Bahasa Indonesia dapat menerapkan pendekatan kontekstual (CTL) dalam rangka meningkatkan keterampilan menulis laporan., (2) lebih meningkatkan pemahaman dan wawasannya tentang berbagai pendekatan pembelajaran yang sekiranya mampu untuk meningkatkan kompetensi dasar tertentu dalam pembelajaran.

3. Saran untuk Kepala Sekolah, (1) perlu lebih mengupayakan peningkatan profesionalisme guru melalui pelatihan yang berkaitan dengan model-model pendekatan pembelajaran, khususnya mengenai implementasi penerapan pendekatan kontekstual (CTL) dalam meningkatkan keterampilan siswa menulis laporan. (2) perlu mengupayakan tersedianya fasilitas-fasilitas yang dapat menopang terselenggaranya kegiatan pembelajaran, yang menerapkan pendekatan kontekstual (CTL) seperti penyediaan berbagai alat sarana dan prasarana secara memadai.

4. Saran untuk Dinas Pendidikan, dapat memfasilitasi terselenggaranya pelatihanpelatihan bagi pengembangan profesionalisme guru, khususnya yang berkaitan dengan teknik-teknik dan model pendekatan pembelajaran.

\section{Daftar Pustaka}

Anwar Hasnun. 2006. Keterampilan Menulis untuk Siswa SD, SMP, dan SMA. Yogjakarta : Andi

Burhan Nurgiyantoro. 1988. Penilaian dalam Pengajaran Bahasa dan Sastra. Yogyakarta: BPFE.

Depdiknas, 2002a. Pendekatan Kontekstual (Contextual Teaching and Learning). Jakarta : Ditjen Dikdasmen 
, 2004a . "Pembelajaran Penulisan Karya Ilmiah" dalam Materi Pelatihan Terintegrasi Bahasa Indonesia . Jakarta : Ditjen Dikdasmen , 2004b. Pengembangan Kemampuan Menyunting materi Pelatihan Terintegrasi Bahasa Indonesia. Jakarta : Ditjen Dikdasmen

Henry Guntur Tarigan. 1993. Menulis sebagai Suatu Keterampilan Berbahasa. Bandung : Penerbit Angkasa.

Muhibin Syah. 2000. Psikologi Pendidikan . Bandung : Gramedia

Sabarti Akhadiah, Maidar Arsyad, dan Sakura Ridwan. 1997. Menulis I Buku Materi Pokok. Jakarta : Karunika.

Sunardi. 2005 . "Implementasi Pendekatan Contextual Teaching and Learning (CTL) Dalam Pembelajaran Pantun " dalam Jurnal Pendidikan, Vol 2 No 2 Juni 2005. Semarang : LPMP Jawa Tengah

The Liang Gie. 1994. Cara Belajar yang Efisien. Yogyakarta: Liberty.

Winkel, WS. 1987. Psikologi Pengajaran. Jakarta : PT Gramedia.

(http://www.bpgupg.go.id/buletin/akademik/php) 